and Jorge Cepernic dams in Argentina were touted as key energy projects by former president Cristina Fernández de Kirchner, but they are far from the grid and about 2,750 kilometres from Buenos Aires, where energy needs are high. A 2006 feasibility study of 30 dam projects by Argentina's energy ministry ranked them 23rd and 25th, respectively.

In 2015, Chinese company MMG Ltd modified its environmental-impact study for the Las Bambas copper-mining project in Peru's Cotabambas province without consulting local communities. Although compliant with newly modified Peruvian law, the decision provoked demonstrations by local residents that ended in 4 deaths and led Peruvian President Ollanta Humala to declare a 30-day state of emergency in the province.

Despite China's slowing growth and some bad press, the country will - Gallagher reveals - remain one of the region's key economic partners. Last year saw Chinese finance to Latin America and the Caribbean rise to a level surpassed only in 2010, much of it focused on oil, gas and transport infrastructure. Just as US investors did in the decades straddling the turn of the last century, China is seeking to develop transport networks to carry commodities to port, such as the Peru-Brazil railway proposed during Chinese Premier Li Keqiang's 2015 visit to the region.

Latin America also stands to benefit from China's sustained presence. In The Dragon in the Room (Stanford University Press, 2010), Gallagher and Roberto Porzencanski advised nations to capture China's windfall by investing in export diversification. They did not, but Gallagher insists in The China Triangle that it is not too late. He prescribes greater partnerships between countries and markets, and policies that promote equality and environmental stewardship. But postboom, Gallagher foresees a Latin America with less room to manoeuvre, economically and politically. The region would need to appeal to both the United States and China to ensure future growth. Gallagher's 'China triangle' refers to this shift.

The value of diversified partnerships, whether with the United States and China or a wider variety of partners, is increasingly clear to Latin Americans. The region should avoid dependency on rawmaterials exports - and beware of reliance on big powers with deep pockets.

Margaret Myers is director of the China and Latin America programme at the Inter-American Dialogue, a Western Hemisphere affairs think tank in Washington DC.

e-mail:mmyers@thedialogue.org

\title{
Glass half full
}

\author{
Stuart Pimm examines E. O. Wilson's grand vision for \\ an Earth shared equally between humanity and nature.
}

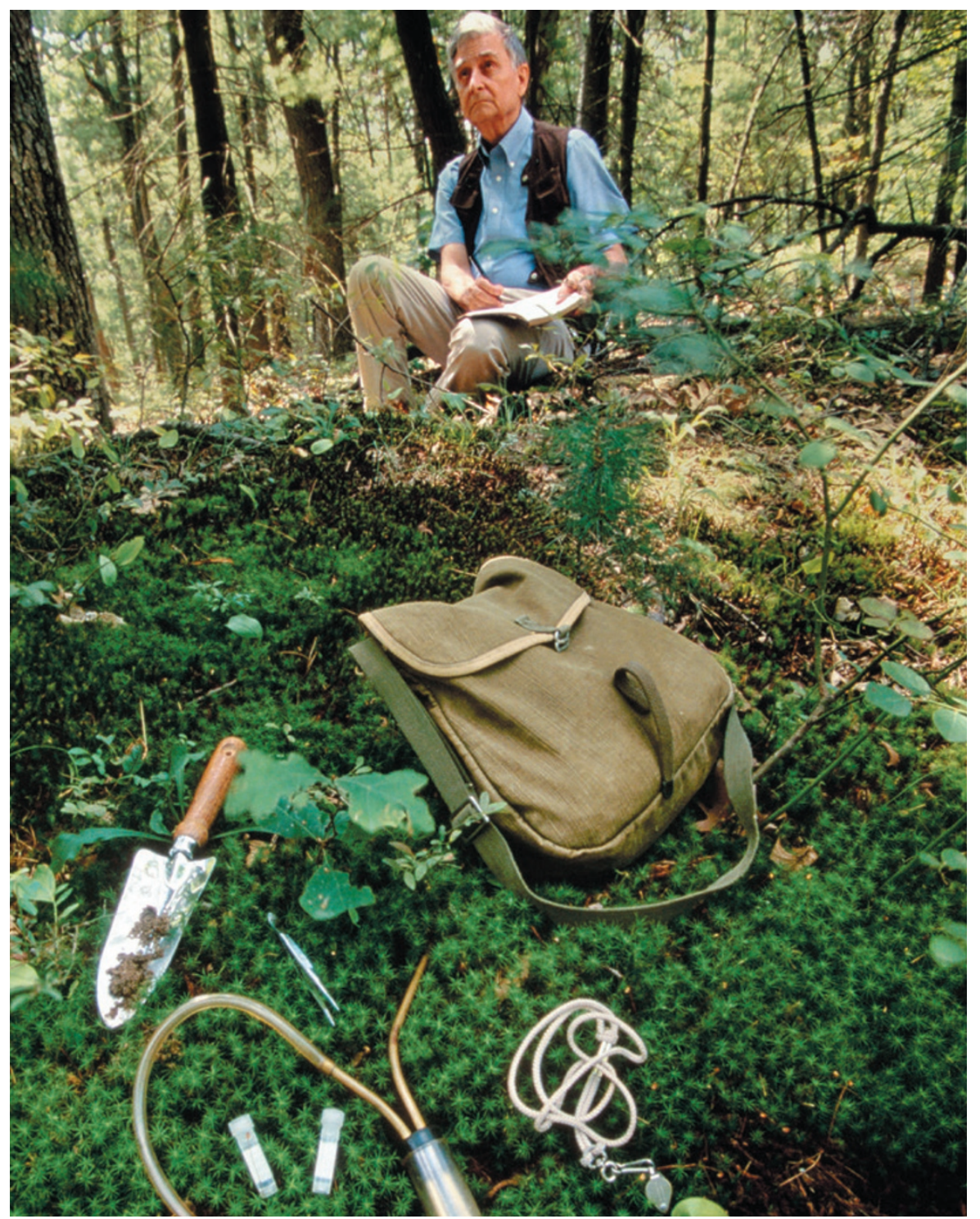

Biologist E. O. Wilson suggests a radical approach to conservation.

W hat do humans want? So asks E. O. Wilson near the start of Half-Earth, his bold vision for the biosphere. He outlines the probable answer: "indefinitely long and healthy life for all, abundant sustainable resources, personal freedom, adventure both virtual and real on demand, status, dignity, membership in one or more respectable groups, obedience to wise rulers and laws, and lots of sex with or without reproduction". He adds: "These are also the goals of your family dog."

The eminent biologist demands that we aspire to much more. He calls for no less than committing half of the planet's surface to a haven for nature. It's an ambitious goal, yet failure would be dire.

This is no isolated argument. Half-Earth is the last in a trilogy. In The Social Conquest of Earth (Liveright, 2012), he marvels at how advanced social organization is rare among animals and how "one species of large-sized African primate" - us - has become not merely dominant, but a force of geological change. In The Meaning of Human Existence (Liveright, 2014), he argues that we are 
"a biological species in a biological world", adapted to going forth and multiplying as if there were no tomorrow. There might not be. Only if we protect 'Half-Earth' can the vast majority of species can be saved.

Wilson's vision begs questions that he does not address in detail. Is it feasible? How close are we to achieving it?

In which ecosystems - forests or deserts or reefs - might we succeed? Where might failure be inevitable? Instead, he presents a manifesto. Half, he says, is a safe limit, because our own survival depends on the services of nature. Wilson argues a psychological need, too. He intends his goal to inspire us to strive nobly against the odds on behalf of all life. We must articulate an endpoint beyond the day-to-day business of saving particular species and habitats.

The consequences of protecting less than half are as close as my local supermarket on Key Largo, Florida, where I do my fieldwork. It is 500 metres from the Atlantic Ocean on one side and the Gulf of Mexico on the other, yet the fishmonger's slab is covered with farmraised salmon and tilapia, and scallops from the Southern Hemisphere. Even the mahimahi - available locally — is from Mexico.

Wilson castigates those who think that there is no problem with humans eliminating species 1,000 times faster than the natural background rate. Will new species evolve as they did after the mass extinction that killed the non-avian dinosaurs? It took evolution 5 million years to restore previous levels of diversity. Will invasive species fill in the gaps? Alien species from rabbits in Australia to zebra mussels in the United States already cause harm costing billions of dollars per year.

Nor is Wilson kind to "new conservation", a movement that he notes is embraced by the large US land trust the Nature Conservancy. Its proponents denigrate those who believe in pristine landscapes and, as he puts it, “prefer 'working landscapes' presumably as opposed to 'lazy and idle' landscapes, thereby making them more acceptable to ... business leaders". A Google search suggests that the term pristine landscapes may have appeared in the flagship journal Conservation Biology once in the past decade - raising the question of who the professionals are who supposedly believe in them.

The Amazon exemplifies what Wilson calls wilderness: regions with small human populations, mainly indigenous ones. Companies that extract resources have historically been insensitive to the cultural disruption, and even genocide, that this can trigger. Wilson emphasizes how cultural diversity and biodiversity are important and can reinforce each other. I share his impression that the individuals most uncaring and dismissive of wilderness and biodiversity are those who have had the least experience of it. As nineteenth-century explorer Alexander von Humboldt put it: “The most dangerous worldview is the worldview of those who have not viewed the world."

Is Half-Earth possible? The trajectories are favourable. About 5 million square kilometres of land and almost none of the oceans were protected in the mid-1970s; now the figures are close to 17 million and 10 million square kilometres, respectively. Vast marine no-take zones have been established annually since 2000. Globally agreed targets aspire to more, and more representative, protection. Large tracts of land - deserts, the Amazon, the boreal forests - are protected because they are remote. The challenge will be to protect areas near cities, or areas that, like temperate grasslands, are easy to convert to livestock grazing.

A change in moral reasoning gives Wilson most hope. A 2015 encyclical letter from Pope Francis contains an outstanding tour of the challenges in mitigating damage to natural habitats. Its moral imperative, that we have no right to do harm, echoes Wilson's concluding sentence: "Do no further harm to the biosphere."

Wilson lauds those who devote their lives to that cause. The degraded longleaf-pine savannahs of the US Gulf coast - neglected by

"We must
articulate
an endpoint
beyond saving
particular
species and
habitats."
federal authorities and land trusts found a champion in the philanthropist M. C. Davis. Entrepreneur Greg Carr has helped to restore Gorongosa National Park in Mozambique after a brutal civil war. Entrepreneurs Douglas and Kristine Tompkins have protected more land worldwide than any other private individuals - and in temperate grasslands, to boot. Progress on Half-Earth is possible in unlikely places. It is an aspiration worthy of our species.

Stuart Pimm is professor of conservation at the Nicholas School of the Environment at Duke University in Durham, North Carolina, and directs the non-profit organization SavingSpecies.

e-mail:stuartpimm@me.com

\section{Sara Reardon is moved by a play about the toll of infant sex-assignment surgery.}

I n 1966, psychologist John Money of Johns Hopkins University in Baltimore, Maryland, met someone who he felt was the research patient of a lifetime. David Reimer, then an eight-month-old boy, had had his penis mutilated in a circumcision accident. Doctors concluded that surgical reconstruction was too difficult. Money proposed a 'solution': could the child be turned into a girl?

Money studied people born with intermediate sex characteristics - then called

hermaphrodites. Standard medical procedure at that time (and still all too often) was to guess the sex that a baby 'should' be and surgically alter their genitals accordingly.

Money believed, as did many psychologists at the time, that the right training and environment could shape a child into any gender as long the process was started early enough. And because there was no doubt about whether

Boy

ANNA ZIEGLER

Clurman Theatre, New

York City.

Until 9 April 2016.
Reimer had been born a boy, and without the other variables such as hormonal or genetic characteristics that can contribute to gender identity in intersex individuals, Money thought that the baby presented the perfect test case for the nurture theory. Reimer even had a control, a twin brother.

This tragic experiment is the inspiration for Anna Ziegler's play Boy, now showing at the Clurman Theatre in New York City. The story cuts between 1989 and the 1970s, following the young adulthood of Adam 